Jurnal Kesehatan 14 (2) 2021, 169-177

\title{
Analisis Risiko Multifaktorial Terhadap Terjadinya Dementia Pada Populasi Wanita Muslim Pra-Lansia / Lansia Di Kabupaten Sukoharjo
}

\author{
Retno Sintowati ${ }^{1}$, Yusuf Alam Romadhon ${ }^{2}$, Sulistyani ${ }^{3}$ \\ ${ }^{1,2,3}$ Program Pendidikan Dokter Fakultas Kedokteran Universitas Muhammadiyah \\ Surakarta \\ Email: ${ }^{1}$ rs160@ums.ac.id ${ }^{2}$ yar245@ums.ac.id ${ }^{3}{ }^{\text {sul271@ums.ac.id }}$
}

Tanggal Submisi: 21 Maret 2020; Tanggal Penerimaan: 17 November 2021

\begin{abstract}
ABSTRAK
Latar belakang: Prevalensi wanita Indonesia untuk mengalami hipertensi dan penyakit jantung lebih besar daripada pria. Wanita Indonesia juga lebih tinggi prevalensi depresi dan gangguan mental emosional dibandingkan pria. Kedua faktor ini merupakan penentu kesehatan pembuluh darah termasuk di dalamnya kesehatan pembuluh darah otak yang berpengaruh terhadap terjadinya dementia. Hingga kini masih sedikit kajian yang lebih komprehensif mengenai faktor risiko terjadinya dementia pada wanita Muslim dengan berbagai risiko yang lebih tinggi. Tujuan: Penelitian ini bertujuan untuk menganalisis faktor-faktor yang berpengaruh terhadap terjadinya dementia pada komunitas wanita Muslim Indonesia. Metoda: Populasi penelitian ini berasal dari peserta posyandu lansia di wilayah kerja Puskesmas Kartasura yang dipilih dengan teknik sampling cluster random. Peserta dianalisis usia, pendidikan, usia menarche, status klimakterium, penggunaan kontrasepsi hormonal, indeks masa tubuh, tekanan darah, gula darah puasa, aktivitas fisik, gangguan mental dengan DASS [depression anxiety stress scale], fungsi kognitif mini mental state examination [MMSE], pemahaman bacaan sholat, dan biomarker molekuler kardiovaskuler seperti hs-CRP, ICAM1 dan interferon gamma diukur dengan pemeriksaan ELISA. Analisis statistic menggunakan korelasi. Hasil: Terdapat 38 wanita Muslim pra-lansia/lansia yang mengikuti prosedur penelitian ini. Dari analisis bivariat adanya korelasi antara usia dengan DASS $(\mathrm{r}=-0.310 \mathrm{p}=0.028)$, kadar gula darah puasa dengan hs-CRP $(\mathrm{r}=0.364 \mathrm{p}=0.024)$, bacaan sholat dengan interferon gamma $(\mathrm{r}=-0.325 \mathrm{p}=0.046)$. Kesimpulan: Pada wanita, gangguan metabolism glukosa meningkatkan inflamasi sistemik kronik, pembuluh darah yang mengalami inflamasi menurunkan fungsi kognitif otak, spiritualitas Islam yang baik menurunkan tingkat inflamasi sistemik.
\end{abstract}

Kata kunci : biomolekuler, demensia, psikososio-spiritual, wanita Jawa Muslim

\section{ABSTRACT}

Background: The prevalence of Indonesian women to experience hypertension and heart disease is greater than that of men. Indonesian women also have a higher prevalence of depression and mental emotional disorders than men. Both of these factors are determinants of blood vessel health, including the health of brain blood vessels which affect the occurrence of dementia. Until now, there is still little more comprehensive study regarding the risk factors for dementia in Muslim women with a higher risk range. Purpose: This study aims to analyze the factors that 
influence the occurrence of dementia in the Indonesian Muslim women's community. Methods: The population of this study came from elderly posyandu participants in the working area of Puskesmas Kartasura who were selected by random cluster sampling technique. Participants were analyzed for age, education, age at menarche, climacteric status, use of hormonal contraceptives, body mass index, blood pressure, fasting blood sugar, physical activity, mental disorders with DASS [depression anxiety stress scale], cognitive function mini mental state examination [MMSE], comprehension of prayer readings, and cardiovascular molecular biomarkers such as hs-CRP, ICAMl and interferon gamma were measured by ELISA examination. Statistical analysis using correlation. Results: There were 38 pre-elderly / elderly Muslim women who followed this study procedure. From the bivariate analysis there is a correlation between age and DASS $(r=-0.310 p=0.028)$, fasting blood sugar levels with $h s$-CRP $(r=0.364 p=0.024)$, prayer readings with interferon gamma $(r=-$ $0.325 p=0.046)$. Conclusion: In women, impaired glucose metabolism increases the risk of chronic systemic inflammation, vascular inflammation decreases brain cognitive function, good Islamic spirituality reduces systemic inflammation level.

Keywords: biomolecular, dementia, Javanese Muslim women, psychosociospiritual,

ISSN 1979-7621 (Print). ISSN 2620-7761 (Online)

DOI 10.23917/jk.v14i2.13974

\section{PENDAHULUAN}

Secara global, prevalensi demensia diperkirakan akan naik dua kali lipat setiap dua puluh tahun dan pada tahun 2050 diperkirakan mencapai 115 juta jiwa (Nussabaum and Ellis, 2003). Penyakit neurodegeneratif merupakan penyebab morbiditas dan disabilitas yang makin mendapatkan perhatian berkaitan dengan dampaknya pada beban sosioekonomik yang luar biasa (Stephenson et al, 2018). Wanita Indonesia dibandingkan pria, lebih berisiko untuk menderita penyakit jantung, penyakit serebrovaskuler dan gangguan mental emosional (Kementerian Kesehatan Republik Indonesia, 2019). Secara umum wanita lebih rentan untuk menderita efek inflamasi dari depresi dibandingkan pria (Bekhbat and Neigh, 2018). Di antara sesama wanita di Indonesia, wanita Muslim lebih rentan untuk menderita hipertensi dibandingkan penganut agama lainnya (Jansen, 2017).

Stres psikososial berkontribusi dalam berkembangnya depresi dan anxietas. Depresi dan anxietas merupakan keadaan yang dapat memicu terjadinya inflamasi sistemik kronik (McKim et al, 2018). Inflamasi sistemik ini merupakan inflamasi steril, yakni inflamasi tanpa adanya infeksi (Johnson et al, 2019). Sedangkan inflamasi sistemik akibat stres dan sebab sistemik lainnya memicu neuroinflamasi memperparah proses patologik dan selanjutnya menginduksi perubahan-perubahan struktur otak yang mempengaruhi fungsi kognitif (d'Avila et al, 2018; Bekhbat and Neigh, 2018; Ferrucci and Fabbri, 2018; Fonken et al, 2018; Ouanes and Pop, 2019). Inflamasi sistemik kronik merupakan mekanisme bersama yang disebabkan oleh berbagai macam keadaan dan muara akibat juga berbagai keadaan yang terkait dengan 
penyakit degeneratif termasuk di dalamnya neurodegeneratif (Farzanfar et al, 2018). Pada mencit model stres sosial mengakibatkan meningkatnya produksi sel-sel inflamatori dari sumsum tulang menuju sirkulasi, kondisi inflamatori sistemik, dan peningkatan molekul adesi neurovaskuler yang teraktivasi melalui jalur HPA aksis dan sistema syaraf simpatis (Niraula et al, 2018). Problem inflamasi bukan pada bagaimana memulainya, tetapi pada bagaimana inflamasi tersebut diredakan (Skaper et al, 2018). Olah raga sebaliknya dapat menurunkan kadar biomarker inflamatori sehingga dapat menjaga fungsi neurokognitif (Ashcraft et al, 2018).

\section{METODE PENELITIAN}

Penelitian ini berdesain potong lintang menganalisis korelasi antar variabel dalam satu waktu. Peserta penelitian ini adalah anggota posyandu lansia. Peserta dianalisis usia, pendidikan, usia menarche, status klimakterium, penggunaan kontrasepsi hormonal, indeks masa tubuh, tekanan darah, gula darah puasa, aktivitas fisik, gangguan mental dengan DASS [depression anxiety stress scale] 42 pertanyaan, pemahaman bacaan sholat, dan biomarker molekuler kardiovaskuler seperti hs-CRP [high sensitive $C$ reactive protein], ICAM1 [intercelulare adhesion molecule 1] dan interferon gamma diukur dengan pemeriksaan ELISA. Data kadar biomarker inflamasi hs-CRP, ICAM-1, dan interferon gamma didapatkan dari pemeriksaan ELISA serum dari darah vena subyek diambil di jam 06.30 hingga 08.30 pagi, setelah puasa semalam. Variabel dependen, yakni fungsi kognitif otak atau seberapa besar tingkat dementia diukur dengan menggunakan pemeriksaan mini mental state examination [MMSE].

Data-data variabel tergantung dalam skala kontinu untuk dilakukan uji beda mean menggunakan uji $t$ tidak berpasangan bila distribusi data normal, bila tidak normal menggunakan uji Mann Whitney U. Korelasi antar variabel kontinu diuji dengan korelasi Pearson apabila distribusi data normal, sebaliknya bila tidak normal diuji dengan korelasi Spearman. Data-data variabel tergantung dalam skala kategorik, untuk analisis bivariat menggunakan Chi square.

\section{HASIL DAN PEMBAHASAN}

Sejumlah 38 peserta berpartisipasi dalam penelitian ini, sebagian besar berusia pra lansia [di bawah 60 tahun], menjalani pendidikan formal 12 tahun lebih, menikah di rentang usia $20-30$ tahun, usia menarche 13 tahun lebih, belum menopause, menggunakan kontrasepsi hormonal, bertekanan darah normal, normoweight, kadar gula darah sewaktu normal, aktivitas fisik ringan, dan berisiko kardiovaskuler sedang/tinggi (Tabel 1). Pada analisis bivariat tidak didapatkan satupun faktor risiko yang dianalisis menunjukkan pengaruh yang signikan terhadap terhadap terjadinya demensia (Tabel 2). 
R Sintowati, Y A Romadhon, Sulistyani / Jurnal Kesehatan 14 (2) 2021, 169-177

Tabel 1. Karakteristik responden

\begin{tabular}{|c|c|c|c|}
\hline Variabel & Atribut & Frekuensi & Prosentase \\
\hline \multirow{2}{*}{ Usia } & Pra lansia & 30 & $78.9 \%$ \\
\hline & Lansia & 8 & $21.1 \%$ \\
\hline \multirow[t]{2}{*}{ Pendidikan } & $\geq 12$ tahun & 29 & $76.3 \%$ \\
\hline & $<12$ tahun & 9 & $23.7 \%$ \\
\hline \multirow[t]{2}{*}{ Usia menikah } & $20-30$ tahun & 26 & $68.4 \%$ \\
\hline & $<20$ tahun atau $>30$ tahun & 11 & $31.6 \%$ \\
\hline \multirow[t]{2}{*}{ Usia menarche } & $\geq 13$ tahun [rerata] & 20 & $52.6 \%$ \\
\hline & $<13$ tahun & 18 & $47.4 \%$ \\
\hline \multirow{2}{*}{ Status Klimakterium } & Menopause & 18 & $47.4 \%$ \\
\hline & Belum menopause & 20 & $52.6 \%$ \\
\hline \multirow[t]{2}{*}{ Jenis kontrasepsi } & Hormonal & 22 & $57.9 \%$ \\
\hline & Non hormonal / tidak & 16 & $42.1 \%$ \\
\hline \multirow[t]{2}{*}{ Tekanan darah } & Borderline/Hipertensi & 17 & $44.7 \%$ \\
\hline & Normotensi & 21 & $55.3 \%$ \\
\hline \multirow[t]{2}{*}{ Indeks masa tubuh } & Overweight/obese & 14 & $36.8 \%$ \\
\hline & Normoweight & 24 & $63.8 \%$ \\
\hline \multirow[t]{2}{*}{ Kadar gula darah puasa } & Tinggi & 6 & $15.8 \%$ \\
\hline & Normal & 32 & $84.2 \%$ \\
\hline \multirow[t]{2}{*}{ Aktivitas fisik } & Ringan & 26 & $68.4 \%$ \\
\hline & Sedang/berat & 12 & $31.6 \%$ \\
\hline \multirow[t]{2}{*}{ Risiko kardiovaskuler } & Sedang/tinggi & 26 & $68.4 \%$ \\
\hline & Ringan & 12 & $31.6 \%$ \\
\hline \multirow[t]{2}{*}{ DASS } & $\geq$ rerata & 18 & $47.4 \%$ \\
\hline & $<$ rerata & 20 & $52.6 \%$ \\
\hline \multirow[t]{2}{*}{ Bacaan sholat } & $<$ rerata & 17 & $44.7 \%$ \\
\hline & $\geq$ rerata & 21 & $55.3 \%$ \\
\hline \multirow[t]{3}{*}{ hs-CRP } & $>$ rerata & 24 & $63.2 \%$ \\
\hline & $\leq$ rerata & 14 & $36.8 \%$ \\
\hline & Rerata $=\mathrm{SD}=$ & & \\
\hline \multirow[t]{2}{*}{ ICAM-1 } & $>$ rerata & 9 & $23.7 \%$ \\
\hline & $\leq$ rerata & 29 & $76.3 \%$ \\
\hline \multirow[t]{2}{*}{ Interferon Gamma } & $\begin{array}{l}\text { Rerata }=\mathrm{SD}= \\
>\text { rerata }\end{array}$ & $\begin{array}{l}3 \\
35\end{array}$ & $\begin{array}{l}7.9 \% \\
021 \%\end{array}$ \\
\hline & $\begin{array}{l}\leq \text { rerata } \\
\text { Rerata }=\mathrm{SD}=\end{array}$ & 35 & $92.1 \%$ \\
\hline \multirow[t]{2}{*}{ Kekhusyukan } & $<$ rerata & 17 & $44.7 \%$ \\
\hline & $\geq$ rerata & 21 & $55.3 \%$ \\
\hline \multirow{2}{*}{ MMSE } & $<$ rerata & 19 & $50 \%$ \\
\hline & $\geq$ rerata & 19 & $50 \%$ \\
\hline
\end{tabular}


R Sintowati, Y A Romadhon, Sulistyani / Jurnal Kesehatan 14 (2) 2021, 169-177

Tabel 2. Analisis bivariat risiko terjadinya dementia

\begin{tabular}{|c|c|c|c|c|}
\hline No & Variabel & $\mathbf{O R}$ & $95 \%$ confidence interval & $p$ \\
\hline & Usia (ref pra lansia) & 3.923 & $0.678-22.705$ & 0.127 \\
\hline & Pendidikan (ref pendidikan $\geq 12$ tahun) & 4.958 & $0.873-28.152$ & 0.071 \\
\hline & Usia menarche (ref $\geq 13$ tahun [rerata]) & 0.424 & $0.115-1.562$ & 0.197 \\
\hline & Usia menikah (ref $20-30$ tahun) & 1.000 & $0.255-3.928$ & 1.000 \\
\hline & Status klimakterium (ref belum menopause) & 3.714 & $0.969-14.233$ & 0.056 \\
\hline & Kontrasepsi (ref non hormonal) & 1.543 & $0.422-5.639$ & 0.512 \\
\hline & Indeks masa tubuh (ref normoweight) & 0.635 & $0.166-2.396$ & 0.502 \\
\hline & Tekanan darah (ref normotensi) & 1.905 & $0.521-6.962$ & 0.330 \\
\hline & Kadar gula (ref normal) & 2.267 & $0.362-14.185$ & 0.382 \\
\hline & Aktivitas fisik (ref sedang/berat) & 1.633 & $0.410-6.509$ & 0.487 \\
\hline & Risiko kardiovaskuler (ref risiko ringan) & 2.727 & $0.652-11.400$ & 0.169 \\
\hline & DASS (ref di bawah rerata) & 1.000 & $0.280-3.574$ & 1.000 \\
\hline & Bacaan sholat (ref $\geq$ rerata) & 0.808 & $0.225-2.909$ & 0.744 \\
\hline & hs-CRP (ref $\leq$ rerata) & 0.635 & $0.168-2.396$ & 0.502 \\
\hline & ICAM1 $($ ref $\leq$ rerata $)$ & 0.406 & $0.085-1.947$ & 0.260 \\
\hline & Interferon gamma $($ ref $\leq$ rerata $)$ & 2.188 & $0.176-25.549$ & 0.555 \\
\hline & Kekhusyukan (ref $\geq$ rerata) & 0.808 & $0.225-2.909$ & 0.744 \\
\hline
\end{tabular}

Pada uji korelasi dengan berkorelasi positif dengan tingkat menggunakan analisis Spearman, demensia, dan skor bacaan sholat didapatkan bahwa usia berkorelasi berkorelasi negative dengan kadar negative dengan gangguan mental, kadar interferon gamma. Korelasi tersebut, gula darah berkorelasi positif dengan secara statistic signifikan (Tabel 3). peningkatan kadar hs-CRP, ICAM-1

Tabel 3. Korelasi Spearman antar variabel yang secara statistic signifikan

\begin{tabular}{llll}
\hline Variabel1 & Variabel 2 & Nilai r & $\boldsymbol{p}$ \\
\hline Usia & DASS & -0.310 & 0.028 \\
Kadar gula darah puasa & hs-CRP & 0.364 & 0.024 \\
ICAM1 & MMSE & 0.346 & 0.033 \\
Bacaan sholat & Interferon Gamma & -0.325 & 0.046 \\
\hline
\end{tabular}

Pada uji komparasi didapatkan kadar hs-CRP pra-lansia lebih tinggi dibandingkan lansia, usia menarche lebih tua didapatkan kadar interferon gamma lebih tinggi dibandingkan yang muda, sedangkan wanita yang belum menopause didapatkan lebih tinggi tingkat gangguan mentalnya, sedangkan pemahaman bacaan sholat yang rendah lebih tinggi kadar ICAM-1 mereka. Perbedaan-perbedaan ini secara statistic signifikan (Tabel 4). 
Tabel 4. Komparasi mean antar variabel yang secara statistic signifikan

\begin{tabular}{lccl}
\hline Variable bebas / atribut & Variabel tergantung & $\boldsymbol{p}$ & Keterangan \\
\hline Usia & hs-CRP & 0.05 & Mann-Whitney \\
Pra lansia & $0.0197 \pm 0.00765 \mathrm{mg} / \mathrm{L}$ & & \\
Lansia & $0.0138 \pm 0.00518 \mathrm{mg} / \mathrm{L}$ & & \\
Usia menarche & Interferon gamma & 0.025 & Mann-Whitney \\
$\geq 13$ tahun [rerata] & $1.30 \pm 0.86$ & & \\
$<13$ tahun & $0.00 \pm 0.00$ & \multirow{2}{*}{0.05} & T test \\
Status klimakterium & DASS & & \\
Menopause & $9.15 \pm 1.38$ & & \\
Belum menopause & $15.17 \pm 2.22$ & 0.011 & Mann-Whitney \\
Bacaan sholat & ICAM1 & & \\
$<$ rerata & $5.24 \pm 2.16$ & & \\
$\geq$ rerata & $2.15 \pm 1.18$ &
\end{tabular}

Dalam penelitian ini didapatkan bahwa pada wanita Muslim, didapatkan empat temuan utama. Pertama, bertambahnya usia menurunkan kemungkinan gangguan mental. Kemungkinan penjelasnya adalah kematangan psikologis dengan bertambahnya usia. Setelah usia lebih tua, peluang terjadinya gangguan mental lebih besar lagi (Uddin et al, 2019). Kedua, gangguan metabolism glukosa meningkatkan inflamasi sistemik kronik. Dari kepustakaan didapatkan bahwa pada penderita diabetes dalam jangka panjang dapat menurunkan fungsi kognitif dan mengarah pada demensia (Pugazhenthi et al, 2017). Hasil penelitian ini sejalan dengan tinjauan teoretis tersebut. Ketiga, pembuluh darah yang mengalami inflamasi menurunkan fungsi kognitif otak. Keberadaan komorbid pada demensia, umumnya terkait dengan inflamasi yang menarget pembuluh darah seperti penyakit kardiovaskuler pada umumnya (Aigbogun et al, 2017). Intervensi yang menarget inflamasi pada pembuluh darah mempunyai dampak yang baik dalam memperbaiki fungsi kognitif (Anton et al, 2018). Salah satu tanda dari lanjut usia adalah tingginya peluang terjadinya inflamasi sistemik kronik. Lebih lanjut inflamasi sistemik kronik tersebut meningkatkan risiko menurunnya fungsi kognitif melalui mekanisme inflamasi yang terjadi di pembuluh darah otak (Ashraf-Ganjouei et al, 2020). Hasil penelitian ini sejalan dengan gagasan tersebut. Keempat, spiritualitas Islam yang baik menurunkan tingkat inflamasi sistemik. Dari berbagai studi kepustakaan didapatkan bahwa spiritualitas Islam yang baik, akan memudahkan tercapainya keadaan relaks dan lebih lanjut akan memperbaiki keadaan inflamasi sistemik pada pasien berisiko (Sholeh, 2000; Doufesh et al, 2014, Senik et al, 2013).

\section{KESIMPULAN}

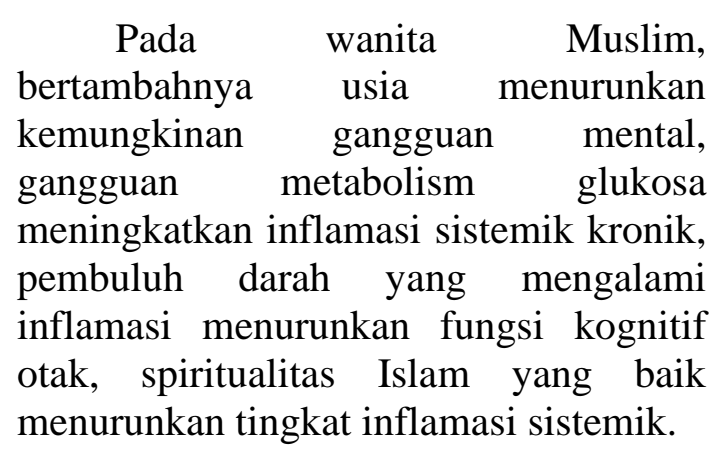




\section{DAFTAR PUSTAKA}

Aigbogun, M.S., Stellhorn, R., Krasa, H., Kostic, D. (2017) Severity of memory impairment in the elderly: Association with health care resource use and functional limitations in the United States, Alzheimers Dement (Amst). 2017; 8: $51-59$

Anton, S.D., Ebner, N., Dzierzewski, J.M., Zlatar, Z.Z., Gurka, M.J., Dotson, V.M., Kirton, J., Mankowski, R.T., Marsiske, M., Manini, T.M. (2018) Effects of 90 Days of Resveratrol Supplementation on Cognitive Function in Elders: A Pilot Study, J Altern Complement Med. Jul 1; 24(7): 725-732.

Ashcraft, K.A., Warner, A.B., Jones, L.W., Dewhirst, M.W. (2018) Exercise as Adjunct Therapy in Cancer, Semin Radiat Oncol 29:16-24

Ashraf-Ganjouei, A., Moradi, K., Bagheri, S., Aarabi, M.H. (2020) The association between systemic inflammation and cognitive performance in healthy adults, $J$ Neuroimmunol Vol 345, 15 Aug, 577272

Bekhbat, M., Neigh, G.N. (2018) Sex differences in the neuro-immune consequences of stress: Focus on depression and anxiety, Brain Behav Immun . 2018 January ; 67: 1-12. Author manuscript; available in PMC 2019 January 01.

d'Avila, J.C., Siqueira, L.D., Mazeraud, A., Azevedo, E.P., Foguel, D., Castro-FariaNeto, H.C., Sharshar, T., Chrétien, F., Bozza, F.A. (2018) Age-related cognitive impairment is associated with long-term neuroinflammation and oxidative stress in a mouse model of episodic systemic inflammation, Journal of Neuroinflammation (2018) 15:28

Doufesh, H., Ibrahim, F., Ismail, N.A., Ahmad, W.A.W. (2014) Effect of Muslim Prayer (Salat) on a Electroencephalography and Its Relationship with Autonomic Nervous System Activity, The Journal of Alternative and Complementary Medicine Vol 20, No 7, pp. 558 - 562

Farzanfar, D., Dowlati, Y., French, L.E., Lowes, M.A., Alavi, A. (2018) Inflammation: A Contributor to Depressive Comorbidity in Inflammatory Skin Disease, Skin Pharmacol Physiol 2018;31:246-251

Ferrucci, L., Fabbri, E. (2018) Inflammageing: chronic inflammation in ageing, cardiovascular disease, and frailty, Nat Rev Cardiol . 2018 September ; 15(9): 505-522. Author manuscript; available in PMC 2018 September 20.

Fonken, L.K., Frank, M.G., Gaudet, A.D., Maier, S.F. (2018) Stress and aging act through common mechanisms to elicit neuroinflammatory priming. Brain, Behavior, and Immunity (2018), https://doi.org/10.1016/j.bbi.2018.07.012

Jansen, N. (2017) Between- and Within-Religion Differences in Hypertension Risks for Indonesian Women, Population Association of America Annual Meeting Final Program, April $27-29$ 
Johnson, J.D., Barnard, D.F., Kulp, A.C., Mehta, D.M. (2019) Neuroendocrine Regulation of Brain Cytokines After Psychological Stress, J Endocrine Soc Vol. 3, Iss. 7 1302-1320

Kementerian Kesehatan Republik Indonesia (2019) Laporan Nasional Riset Kesehatan Dasar 2018, Lembaga Penerbit Badan Penelitian dan Pengembangan Kesehatan Kementerian Kesehatan Republik Indonesia

McKim, D.B., Weber, M.D., Niraula, A., Sawicki, C.M., Liu, X., Jarrett, B.L., RamirezChan, K., Wang, Y., Roeth, R.M., Sucaldito, A.D., Sobol, C.G., Quan, N., Sheridan, J.F., Godbout, J.P. (2018) Microglial recruitment of IL-1 $\beta$ producing monocytes to brain endothelium causes stress-induced anxiety, Mol Psychiatry. 2018 June; 23(6): 1421-1431. Author manuscript; available in PMC 2018 July 03

Niraula, A., Wang, Y., Godbout, J.P., Sheridan, J.F. (2018) Corticosterone Production during Repeated Social Defeat Causes Monocyte Mobilization from the Bone Marrow, Glucocorticoid Resistance, and Neurovascular Adhesion Molecule Expression, The Journal of Neuroscience, February 28, 201838 (9): 2328 - 2340

Nussbaum RL, Ellis CE. Alzheimer's disease and Parkinson's disease. $N$ Engl J Med. 2003;348(14):1356-64. https://doi.org/ 10.1056/NEJM2003ra020003.

Ouanes, S., Popp, J. (2019) High Cortisol and the Risk of Dementia and Alzheimer's Disease: A Review of the Literature. Front. Aging Neurosci. 11:43. doi: 10.3389/fnagi.2019.00043

Pugazhenthi, S., Qin, L., Reddy, P.H. (2017) Common Neurodegenerative Pathways in Obesity, Diabetes, and Alzheimer's Disease, Biochim Biophys Acta. May; 1863(5): 1037-1045.

Senik, M.R., Abdul-Wahab, M.N., Zamani, M. (2013) The Study Of heart rate variability (hrv) Biofeedback Through Zikir (Islamic Recitation) of High School Students, Proceed Malay Tech Univ Conf Engin \& Tech (MUCET) 3-4 December, Kuantan, Pahang

Sholeh, M. (2000) Pengaruh Sholat Tahajjud terhadap Peningkatan Perubahan Respon Ketahanan Tubuh Imunologik, Disertasi: Universitas Airlangga Surabaya

Skaper, S.D., Facci, L., Zusso, M., Giusti, P. (2018) An Inflammation-Centric View of Neurological Disease: Beyond the Neuron. Front. Cell. Neurosci. 12:72. doi: 10.3389/fncel.2018.00072

Stephenson, J., Nutma, E., van der Valk, P., Amor, S. (2018) Inflammation in CNS neurodegenerative diseases, Immunology, 154, 204-219

Uddin, Md.T., Kabir, A., Islam, Md.N. (2019) Prevalence and Determinants of PsychologicalStress of Elderly in Bangladesh: A CrossSectional Study, Indian J Gerontol, Vol. 33, No. 4, pp. 381-392 
R Sintowati, Y A Romadhon, Sulistyani / Jurnal Kesehatan 14 (2) 2021, 169-177 